\title{
IRAN'S FOREIGN POLICY AND EVOLVING ROLE OF SOUTH-SOUTH COOPERATION
}

\author{
L. Zaccara \\ Qatar University, Doha, Qatar
}

\begin{abstract}
The Islamic Republic of Iran is one of the most active players in the framework of SouthSouth cooperation. During the Cold War period Iran treated South-South cooperation as an instrument for providing an independent foreign policy and defending the rights of "oppressed" peoples from the influence of colonizers and imperialists. Nowadays this vector of cooperation is used by Iran as tool for gaining regional superiority in the Middle East and the Muslim world in general.

This article describes the Iranian foreign policy strategy and determinants from the Shah Pahlavi period until Hassan Rouhani presidency in order to assess whether the tools used to foster South-South cooperation for becoming regional power and achieving international recognition by the international community were useful. The author uses qualitative methodology in order to answer the following research questions: to analyze the Iran's foreign policy literature, to identify the SSC initiatives in the post-bipolar era during the presidency of Hashemi Rafsanjani, Khatami, Ahmadinejad and Rouhani, to explain the essence of "non-aligned strategy" and third-worldism.

The article also covers the participation of Iran in the international institutions of the Global South, including Non-Aligned Movement (NAM), Organization of Islamic Cooperation (OIC), G77, etc.
\end{abstract}

Key words: Iran, South—South cooperation, the Islamic Revolution, "non-aligned strategy", the "Dialogue among Civilizations" (DaC), third-worldism

\section{IRAN AND INTERNATIONAL ORGANIZATIONS OF THE GLOBAL SOUTH}

The Islamic Republic of Iran, established in 1979 after the revolution led by the ayatollah Ruhollah Khomeini, has consistently used the multilateralism as one of the main strategies of its foreign policy, mainly towards Third World countries, and in order to enhance South-South cooperation in a very sensitive and "hyper-penetrated" regional environment. However, this multilateral strategy was not originated in 1979, since the previous Pahlavi rulers also used it — although with a different variations and diverse ideological, political and strategic considerations.

Iran, ruled by the last Shah Mohammad Reza Pahlavi, was one of the 29 independent countries that participated in the Bandung Conference in 1955, which can be considered the precedent of the South - South cooperation initiatives within developing countries [Acharya 2016]. Since 1964 Iran has been a member of Group of 77, created by developing nations to promote collective economic interest and enhance lobbying capacity within the United Nations context ${ }^{1}$. Iran presided it in 1973 with the Shah

${ }^{1}$ For more information on the Group of 77, see Joint Declaration of the Seventy-Seven Developing Countries Made at the Conclusion of the United Nations Conference on Trade and Development. URL: http://www.g77.org/doc/Joint\%20Declaration.html (accessed 10.11. 2015). 
Pahlavi as ruler, and again in 2001, under the reformist Mohammad Khatami presidency. Iran is also a member of the Group of 24, a chapter of the G77 established in 1971 to coordinate positions on monetary and financial issues.

Moreover, Iran is a founding member of the Organization of Islamic Cooperation (OIC), created in 1969, but it was not until 1997 when Tehran hosted for first and only time the $8^{\text {th }}$ Summit, with President Khatami as a host. This summit represented one of the peaks of Iranian multilateral South - South cooperation initiatives, following the Dialogue among Civilizations proposed by Khatami at the meeting and assumed later by the United Nations General Assembly.

Perhaps the most relevant case of South-South cooperation of Iran is being member of the Organization of the Petroleum Exporting Countries (OPEC). The Shah Pahlavi was one of the five heads of state founding the intergovernmental organization at the Baghdad meeting in $1960^{2}$. However, not always Iran was able to use its membership to influence on the decisions made at OPEC, mainly after the Islamic Republic was established, and especially during specific circumstances in which the conflict with other members (Iraq and Saudi Arabia) blocked any possible understanding. Moreover, even though in 1973 the use of oil as a political tool by producer countries to pressure developed ones on the Palestine issue, OPEC proved to be inefficient in sustaining high or low prices - according to the needs. The lack of accomplishment by the member states and others, like Russia or Mexico, even not being OPEC members but having the potential capacity to influence the market as well, prevented the oil cartel to make their decisions binding ones.

After the Islamic Revolution, Iran maintained the membership in all the organizations and groups in which the previous government had engaged with - with the exception of $\mathrm{CENTO}^{3},-$ and became a member of new ones, that somehow reflected the new ideological and strategic orientation of the Iranian foreign policy. For instance, Iran joined the Non-Aligned Movement (NAM) in 1979, materializing the disconnection with the previous foreign policy orientation that the Shah had in relation with the United States. Iran hosted the $16^{\text {th }}$ NAM Summit in 2012, with M. Ahmadinejad as a host, and some very relevant figures such as the then Egyptian President Mohammed Morsi the first one visiting Iran since the Islamic Revolution; the Secretary General of the United Nations Ban Ki-Moon; the Qatari Emir Hamad bin Khalifa Al Thani; the Pakistani President Asif Zardari; and the North Korean President Kim Yong-Nam. The high profile of the attending officials was considered as a diplomatic achievement for Ahmadinejad's administration in the midst of the turmoil and controversy surrounding

${ }^{2}$ In the Baghdad initial meeting five nations were present, Iran, Iraq, Kuwait, Saudi Arabia and Venezuela. Currently, 15 countries belong to the OPEC, including Algeria, Angola, Ecuador, Equatorial Guinea, Gabon, Libya, Nigeria, Qatar, Congo and UAE.

3 The Central Treaty Organization (CENTO), originally known as the Baghdad Pact or the Middle East Treaty Organization (METO), was a military alliance created in 1955 and initially formed by Iran, Iraq, Pakistan, Turkey and the United Kingdom, joined by the United States in 1958. It was dissolved in 1979 after the withdrawal of the Islamic Republic of Iran. 
Iranian posture in the Arab Spring scenarios, mainly after the NAM final communique recognized the Iranian right to pursue a civil nuclear program ${ }^{4}$.

Within the NAM context, Iran became a founding member of the Group of 15 , created in Belgrade in 1989. The group that includes countries from Africa, Asia, South and North America aims to cooperate in areas of investment, trade and technology. The $14^{\text {th }}$ — and so far the last - of the Group of 15 summits was held in Tehran, on May 2010, hosted by the president Mahmoud Ahmadinejad, and with the presence of the then Brazilian President Luiz Inácio (Lula) da Silva, and the Turkish Prime Minister Recep Tayyip Erdogan ${ }^{5}$. On the sidelines of that meeting, the three heads of government negotiated an agreement for a nuclear fuel-swap deal with Russia, in order to revive the nuclear negotiations with the $\mathrm{P} 5+1$ group, an initiative that was rejected by the United States.

Furthermore, Iran hosted the founding meeting of the Economic Cooperation Organization (ECO) in 1985. The ECO is the successor of the previous Regional Cooperation for Development (RCD), created in 1964 and terminated in 1979. Initially Iran, Pakistan and Turkey formed it, but it was extended in 1992 to seven new Central Asian states ${ }^{6}$.

Finally, the Gas Exporting Countries Forum (GECF) was established in Tehran in 2001. This forum tries to establish common policies on gas production and export, but without being a cartel as OPEC is. Headquarters is in Doha, and an Iranian diplomat Hussein Adeli was his Secretary General until $2017^{7}$.

\section{A REGIONAL POWER ASPIRATION}

Iran has long competed for power and influence with other countries in the Middle East, a competition characterized by territorial conflict, cultural differences, as well as, since the late 1970's, ideological contention. In fact, a common element in a large part of the foreign policy analysis literature on Iran is the assumption that the permanent objective of Iran is to become a key player in the region, not just in the Persian Gulf, but also the greater Middle East and Central Asia. Eventually, the scope of the Iranian objective went beyond these regional boundaries, as it happened during the times of the Shah Reza Pahlavi, but also following the revolutionary and anti-imperialistic blueprint of the Islamic Revolution that aimed to be universal. What those abovementioned regions have in mind is that belong to what is perceived as Developing or Third World states, which along the second half of the $20^{\text {th }}$ century tried to avoid the penetration by either of the Superpowers of the Cold War, United States and the Soviet Union.

${ }^{4}$ Hiro D. Non-Aligned Summit Belies Isolation of Iran. Yale Global Online. 2012. URL: https://yaleglobal.yale.edu/content/non-aligned-summit-belies-isolation-iran (accessed 10.07.2017).

${ }^{5}$ For more information on the Group of 15, see About G-15. URL: http://g15.org/membercountries-2/ (accessed 10.11. 2015).

${ }^{6}$ For more information on the Economic Cooperation Organization see Member States. URL: http://eco.int/index.php? module $=$ cdk\& func $=$ loadmodule\&system $=$ cdk\&sismodule $=$ user/content_v iew.php\&sisOp=view\&ctp_id=23\&cnt_id=85059\&id=3403 (accessed 10.07. 2017).

7 For more information on the Gas Exporting Countries Forum see GECF Country List. URL: https://www.gecf.org/countries/country-list.aspx (accessed 10.07. 2017). 
Studies of Iran's foreign policy have generally concurred with the characterization that it is a very important actor in the Persian Gulf and Middle East region. But, beyond definitions based on actual or potential capabilities, scholars note that a fundamental element for the categorization of a state as a regional power is the acceptance of its status by the states with which it shares a regional system or subsystem, and, as well, on the part of the great powers that control or determine the rules of the game of the international system [Zaccara 2016a]. Thus, it is evident that a regional power is such because it can exercise its greatest capacity to influence at the regional level, although it may intend to project power also on the international level. In this sense, Iran's foreign policy objectives generally align with its resources and capabilities, and on occasion, it has shown an intent to carry out political and diplomatic initiatives beyond the region. This predisposition to surpass its sphere of influence, in many cases with satisfactory results - for instance, its "Dialogue of Civilizations" initiative that was accepted within the Islamic Conference and the United Nations (UN) in 2001 - is a factor to keep in mind in categorizing Iran as not only a regional power, in accordance with the previous classification, but also as a state with "great power" aspirations. The international range of Iranian aspirations may be confirmed by the fact that Iran had been trying to become a nuclear power since the times of the Shah Pahlavi, who launched a nuclear program in 1967. Since then, Iran has had the same clear objective of becoming a member of the "nuclear club," and even though a tough series of sanctions from the UN Security Council (UNSC), the European Union (EU), and the United States have all affected the development of the program, the Iranian economy, and population, mainly since 2006, the final objective seems to have been achieved: to be recognized as a regional power with a supervised nuclear program that can foster its global prestige.

Bearing in mind this long-term objective, matched with the difficulties of being recognized as a regional power by its immediate neighboring states and the superpowers, provided the evidence that Iran needed to generate alternative strategies of cooperation beyond the aforementioned states. South-South cooperation with regional but also with extra regional states represented the opportunity to exert Iranian influence outside the Middle East and to gain legitimacy as an even broader international power. As we will see in the following paragraphs, the Islamic Revolution provided the ideological depth to the Iranian foreign policy objective that made Khomeini, Khatami and even Ahmadinejad, political figures in very varied geographical contexts such as Central Africa or South America.

\section{THE DETERMINANTS OF THE IRANIAN FOREIGN POLICY}

While systemic changes have facilitated as well as hindered Iran's search for status, independent of regime type, it is also true that Iran has exercised some appeal by its promotion of its ideology and culture. This reasoning applies not only to its attraction to other Islamic countries and peoples but also to the support it has received from the non-aligned nations.

One of the guiding principles of Iranian foreign policy of the Islamic Republic is the affirmation of the unity of the Muslim nations and people and the rejection of political 
or other divisions among them ${ }^{8}$. It can be assumed that Iranian foreign policy is geared toward the achievement of this unity, through the conversion of Iran into a spiritual, and material, guide. Due to this universalistic Islamic claim, the authorities hardly ever refer to the Shia-Sunni divide. The revolution was undertaken in the name of those dispossessed and oppressed by a corrupt and un-Islamic government, and Khomeini considered that the majority of the governments of Muslim countries were also illegitimate. The result was the export of the revolution. "It is very clear that for Khomeini and his followers his revolution would not make sense if it was limited only to Iran. The internationalization thereof was vital since Iran was the vanguard, a sort of prophetcountry that should take its message of redemption to the rest of the world" [Rodriguez Zahar 1991]. And so therefore, a project of foreign policy was undertaken in which the fundamental role was played by Islam, with the universal advocacy of the project limited to the Muslim world.

The export of the revolution is one of the most debated topics of Iranian foreign policy as it seemed to be a primary foreign policy objective during the first decade of the republic. It became part of the discussions between the different factions about the consolidation of the revolution in Iran and its expansion. During the first few years of the republic export was a priority along with the institutionalization of the revolution, in what has been referred to as the "twin revolution" [Esposito, Piscatori 1990]. According to Ramazani, it was when Mir Hussein Musavi was Prime Minister (19811989) that the principle of exporting the revolution was implemented. Acting also as foreign minister, he advocated for the creation of a "global Islamic front" against imperialism throughout the world [Ramazani 1990]. The export of the revolution as a driving foreign policy objective was later on downgraded, once the war with Iraq ended and the founder of the revolution died in 1989. Iran was then in need of economic reconstruction and began to seek better relations with the western and neighboring states. From the principles identified by Ramazani, the anti-imperialism and the independence from the East - West confrontation are the ones that clearly defined the Third Worldist and Non-Aligned approach of the new Iranian foreign policy 9 .

These ideological principles, deeply influenced by a mixture of an innovative Shia religious doctrine and a revolutionary third-worldism and anti-imperialism, represented a complete rupture from those that guided the foreign policy of the Shah, and despite the fact that the strategies and instruments have changed in the forty years of Islamic

8 These can be interpreted from the Introduction, and articles 152, 153 and 154 of the Constitution, as well as many speeches delivered by Khomeini since he returned to Iran in February 1979. Also, 'Islamic unity' is mentioned as one of the fixed principles in Iranian Foreign Policy in Eftekhari, A. "The fixed principles of the foreign policy of the Islamic republic of Iran", The Iranian Journal of International Affairs Vol. XIX, No. 2: 27—45 spring 2007.

9 While 'Non-alignment' is mentioned as one of the principles of the Iranian foreign policy in the article 152 of the Constitution, the main slogan coined by its founder Ruhollah Khomeini was na gharbi, na sharqi, jomhuri islami (neither east nor west, Islamic Republic), as an expression of the Iranian interest in abandoning the logic of East-West ideological confrontation to align with Southern countries, societies and concerns. For more information see Imam Khomeini sought NonAligned Movement to play decisive role. URL: http://en.imam-khomeini.ir/en/n21799/Imam Khomeini_sought_Non-Aligned_Movement_to_play_decisive_role (accessed 10.11.2017). 
Republic history, they are still present in the general foreign policy design today. The rhetoric employed by the ayatollah Khamenei, as well as by presidents such as Mahmoud Ahmadinejad, reflects the view that they are still valid justifications of the Iranian stance. For instance, the "resistance economy" and the "heroic flexibility" concepts used by Khamenei in 2012 and 2013 to define the attitude with which the Iranian government and citizens should face international sanctions and nuclear negotiations, is deeply rooted in the same Shia foundational mythology that justified the "heroic resistance" in the early times of the revolution [Khamenei, the Hassan... 2013]. Similarly, Khamenei declared with respect to the Arab Spring that the "events in North of Africa, Egypt, Tunisia and certain other countries have another sense for the Iranian nation... This is the same as 'Islamic Awakening', which is the result of the victory of the big revolution of the Iranian nation"10. In other words, he was asserting the unequivocal and perennial influence of the 1979 Islamic Revolution on the events of the Arab Spring. Hence the official definition of the Arab Spring in the Iranian state-owned media has been and continues to be "Islamic Awakening"11. In this way, Khamenei reproduces the same ideological and religious challenge posted by Khomeini during the revolution. A final example of the durability of those revolutionary principles is that in spite of the tacit approval by Khamenei of the July Joint Comprehensive Plan of Action (JCPOA), he maintains the same discourse of distrust towards the United States, rejecting any possible normalization of relations between the two states ${ }^{12}$.

\section{PRE-REVOLUTIONARY FOREIGN POLICY STRATEGIES}

As mentioned in the introduction, there has been a good deal of continuity in Iran's diplomacy, both before and after the Islamic Revolution, mainly when referred to multilateral approaches to South - South cooperation to reaffirm the Iranian leadership aspirations and in contraposition to the great powers interests. Concepts such as "positive equilibrium", "negative equilibrium", "third power diplomacy", "positive nationalism", "non-alignment" and "independent national policy" were developed over time. Also, "pragmatism", "multilateralism" and "regionalism" have been used by both analysts and Iranian officials to explain their perspective and approach to the foreign policy options and strategies implemented by the different Iranian administrations [Barzegar 2010; Ramazani 2004; Dehshiri, Majidi 2009]. All those concepts refer to strategies implemented in order to achieve the independence of Iran from the great powers in different periods (earlier from Russia - Great Britain, followed by the Soviet Union - United States), but also to achieve Iran's autonomy vis-a-vis the constraints exerted by the regional system, as well as to enhance multilateral cooperation within the SouthSouth context.

${ }^{10}$ Office of the Supreme Leader Sayyid Ali Khamenei. 2011. "Islamic Revolution Inspired Uprisings". March 3. URL: http://www.leader.ir/langs/en/?p=contentShow\&id=7856 (Accessed November 10, 2015).

11 This was evident in the press coverage of the uprisings. See, for example, the Press TV coverage at URL: http://www.presstv.ir/section/IslamicAwakening.html [retrieved January 2015/archived].

12 Gholamzadeh, Hamid Reza. Death to America' is Still Iran's Policy. Mehr News Agency, August 24. URL: http://en.mehrnews.com/news/109482/Death-to-America-still-Iran-s-policy (accessed 10.11. 2015). 
It is important to note that the "equilibrium strategy" that continues to be relevant was introduced in Iranian diplomacy as early as 1848 by the Iranian Prime Minister Mirza Taqi Khan, known as Amir Kabir, who established the notion that Iran should remain impartial between the two great powers at the time, Russia and Britain, rejecting demands that both made on the Iranian government ${ }^{13}$. The same idea was later on implemented by the government of Prime Minister Mohammad Mossadegh, in 1951, as a "negative equilibrium" strategy. Mossadegh nationalized the Anglo-Iranian Oil Company, by then controlled by the British, but also rejected any further involvement with the Soviet Union. This equilibrium strategy failed, and Mossadegh was overthrown with the external support provided by the Central Intelligence Agency in 1953. Both subsequent governments of Shah Reza Pahlavi, like Khomeini's Islamic Revolution, used the same strategy, hence its importance. Under the Shah, strategies of "positive nationalism" and "independent national policy" were devised. "Positive nationalism" was the strategy implemented after the overthrow of Mohammad Mossadegh, and under it both a rapprochement to the Soviet Union as well as the strengthening of relations with the West were justified. The "independent national policy" was coined in the 1960's to promote the cooperation with the USSR as well as a more independent policy toward the United States. Under the ayatollah Khomeini, non-alignment was embraced. Officially implemented by joining the Non-Aligned Movement in 1983, it was mentioned in the Foreign Policy principles stated in the Constitution.

However, the actions undertaken by Shah Reza Pahlavi to implement those strategies consisted mainly of hard power actions, including indirect intervention and direct military action, such as the intervention in Dhofar war in Oman; the involvement in Ethiopia, Iraq, Pakistan and even Vietnam conflicts [Halliday 1979]. This hard power strategy was coped with the Iranian participation in forums such as the OIC, OPEC and G77, which represented the two-sided foreign policy tools used by Shah Pahlavi — military muscle and multilateral diplomacy — to achieve Iranian regional power aim.

\section{THE FOREIGN POLICY STRATEGIES OF THE ISLAMIC REVOLUTION}

The Islamic Republic inaugurated in 1979 used a mixture of hard and soft power instruments to implement its "non-aligned strategy" which was embedded with Shia revolutionary principles and third world and anti-imperialist ideology. Khomeini sought from the outset to raise Iran's regional profile by actively participating in inter-Arab affairs, giving his support to the Palestinian cause, improving relations with Syria, and encouraging Shia minorities in the Gulf and Iraq to rise up against their governments. He also tried at all times to minimize the Arab-Persian and Sunni-Shia dimensions in his speeches, emphasizing instead the Islamic — non-Islamic and oppressor — oppressed

13 The Qajari rulers were not able to prevent the division of Iran into areas of influence between Russia and Great Britain in the 1907 agreements and the occupation of the north of the country by the first, which finally led to the overthrow of the last Qajari monarch and the ascension of the first Pahlavi Shah in 1925. 
dimensions ${ }^{14}$. In this way, he attempted to overcome the nationalistic aspect of the "Islamic Revolution", in order to erase the label of "Iranian Revolution"" that many had already given it. The forums provided by Non-Aligned Movement as well as others in which Iran belonged, resulted fundamental in exerting this new foreign policy approach, as well as it served to establish new mechanism of South-South cooperation within the anti-imperialistic context. The distrust on the United Nations Security Council regarding the management of the war with Iraq (1980-1988) and the regional backlash that Iran received since the revolution encouraged the prosecution of alternative diplomatic tools to break the isolation of Iran and to reach out with Third World states in its struggle against the superpowers.

In the 1990's, the Iranian president Hashemi Rafsanjani (1989-1997) implemented "pragmatism" as the main strategic mechanism to reinsert Iran in the international order [Afrasiabi 1994]. In that sense, the first steps taken were to initiate a reduction of tension with Saudi Arabia and Iraq, and a "critical dialogue" with the EU. The dissolution of the Soviet Union and the emergence of new states in Central Asia in the early 1990's presented a new soft power opportunity for Iran, facilitated by systemic conditions, to implement a new "pragmatic regionalism," not based on religious principles but on common economic and strategic interests and cultural ties. Accordingly, Iran tried to benefit from the linguistic similarities between Iran and Tajikistan on the one hand, and the historical and religious links with Uzbekistan, Armenia, and Azerbaijan on the other. The new situation created in the Caspian Sea, shared now between five states (Iran, Kazakhstan, Russia, Turkmenistan, and Azerbaijan), also forced Iran not to focus on religious considerations but on strategic interest in order to maximize its share. Iranian pragmatism was evident in the Iranian mediation in the Tajik civil war (1992 - 1997), and in the war between Armenia and Azerbaijan on the Nagorno-Karabakh enclave (1988-1994). In the latter case, for strategic reasons Iran sided with Armenia, a country with a majority Christian population, against Azerbaijan, one with a majority Shia population. On this regard, all the Iranian presidents have highlighted the importance given to the ECO organization as a tool of regional cooperation, but also as a mechanism to expand Iranian influence in a region in which the competence between Moscow, Ankara, and even Riyadh, would play a fundamental role in determining the future of Central Asia ${ }^{15}$. The events of the Afghanistan war prove how important Iranian connections with the Afghan Northern Alliance were to guarantee the eventual progress in that front against the Taliban regime.

14 Two of the most relevant documents by Khomeini 'Hokumat-e Islami (Islamic Government)', and 'Imam Khomeini's Last Will and Testament' written in 1970 and 1989 respectively, extensively use to the term 'oppressed' (15 and 39) to refer the peoples, mainly in Muslim states, oppressed either by their own government or any other form of imperial or colonial power. See: Islamic Government. URL: https://web.archive.org/web/20031206165617/http://www.wandea.org.pl/khomeini-pdf/ hukumat-i-islami.pdf (accessed 10.07. 2017); Imam Khomeini's Last Will and Testament. URL: https://www.al-islam.org/printpdf/book/export/html/39086 (accessed 10.07. 2017).

${ }_{15}$ For more information on Rouhani's and Ahmadinejad's administrations regarding ECO. ECO, best option for regional coop. URL: https://theiranproject.com/blog/2018/09/25/ecobest-option-for-regional-coop/ (accessed 10.07. 2017); Iran urges closer cooperation at ECO. URL: http://previous.presstv.ir/ detail.aspx?id=171813\&sectionid=351020102 (accessed 10.07.2017); Rouhani: Tehran highly regards Economic Cooperation Organization. URL: https:/en.trend.az/iran/ politics/2726712.html (accessed 10.07. 2017). 


\section{"DIALOGUE AMONG CIVILIZATIONS" AS SOUTH-SOUTH COOPERATION MODEL}

The eight years of the Mohammad Khatami presidency (1997-2005) were heavily influenced by the emergence of Al Qaeda, the terrorist attacks on September 11, 2001, and the Afghanistan and Iraq wars. Although Iran was labelled and ostracized by the United States as a member of the "Axis of Evil" and a sponsor of terrorism (2002), Khatami reinserted Iran into the international and regional arenas by sponsoring the "Dialogue among Civilizations" (DaC), the most internationally supported initiative started by an Iranian government since the Islamic Revolution. The initiative, which was conceived as a powerful tool of South-South understanding, was presented for the first time at the Eighth Islamic Summit Conference held at Tehran in December 1997 and incorporated in the final statement of the summit. This initiative was based on two discourses made by President Khatami and the leader ayatollah Ali Khamenei. The first speech called for the promotion of confidence building measures in the Middle East and the Gulf countries ${ }^{16}$, and the second for ending the ideological struggle of the Islamic Republic vis-à-vis other Islamic states ${ }^{17}$.

The good reception for Khatami's initiative encouraged the Iranian president to offer the proposal to the $53^{\text {rd }}$ Plenary Session of the United Nations General Assembly, and to ask for 2001 to be declared the International Year of Dialogue among Civilizations. The proposal was accepted on September 21, 1998, and the UN Educational, Scientific, and Cultural Organization was commissioned to plan the cultural, social, and educational program on the Dialogue of Civilizations, including high level conferences and seminars around the world. Khatami's discourse was looking to put on the UN discussion table several international situations in which the Muslim population were suffering, like Afghanistan, Palestine, Kosovo, but stressing the necessity of philosophical discussion about the history and construction of civilizations, and the importance of inter-religious dialogue and the returning to spirituality in civil society.

The first goal of $\mathrm{DaC}$ was cultural discussion and promotion of different visions of the world to eliminate intolerance and intercultural and religious violence. There were not political or security goals in terms of elaboration of concrete policies of fighting against terrorism or wars. We must remind that even the year of DaC was 2001, the proposal was made three years before the New York terrorist attack on September 11, 2001 [Zaccara 2016b].

Even though September 11, 2001 and the resulting wars overshadowed the outcomes of the dialogue, the initiative was able to overcome religious divisions, proving that the Iranian government maintained to some extent the universalistic appeal of the Islamic Revolution, though with a different strategy and diplomatic tone, and attracting the support of almost all the Muslim countries and Third World. The resulting resolutions

16 Khatami M. Statement at the Eighth Session of the Islamic Summit Conference, Tehran, December 9, 1997. URL: https://www.radioislam.org/islam/english/islamwo/khatami.htm (accessed 10.11.2015).

17 Khamenei A. Statement at the Eighth Session of the Islamic Summit Conference, Tehran, December 9, 1997. URL: http://www.islam-pure.de/imam/speeches/speech1997.htm\#09.12.1997 (accessed 10.11. 2015). 
adopted by the United Nations General Assembly, as well as UNESCO resolutions and declarations are the evidence of the successful diplomatic effort made by the Khatami administration is fostering South-South cooperation and dialogue, not only within the Muslim context, but worldwide ${ }^{18}$.

The DaC international year lasted only during 2001, but the cultural activities related to UNESCO program continued from 2003 to 2006. High-level meetings, held in Africa, Asia, Europe and America, covered a wide range of topics related to intercultural, religious and civilizational dialogue ${ }^{19}$. Once the UNESCO program ended in 2006, the activities related to the DaC were continued by the Foundation of Dialogue among Civilizations (FDC), structure established in 2007 "to promote the institution of regular dialogue between the world's peoples, cultures, civilizations and religions in order to promote peace, justice and tolerance", according to their mission statement. The foundation is located in Geneva, and headed by the former Iranian President Mohammad Khatami. The FDC has been keeping alive and active the spirit of the Iranian DaC initiative through a series of meetings and cultural, artistic and scientific activities, involving NGOs and international organizations such as IESCO, ECOSOC, in order to promote "mutual understanding, tolerance, peaceful coexistence and international cooperation and security" 20 .

\section{THIRD-WORLDISM AHMADINEJAD STYLE}

The neo-conservatism of the President Mahmoud Ahmadinejad (2005-2013) was the logical response by the regime in order to maximize regional gains and fortify the resistance against "imperialism", especially in relation to the nuclear program that had come into the spotlight since $2002^{21}$. Ahmadinejad thus inaugurated several new postures in foreign affairs, among them the one that brought to him both detractors and supporters worldwide after statements he made about the holocaust in a speech during the "World Without Zionism" conference held in Tehran in October 2005. Ahmadinejad reproduced a statement issued by Khomeini, the official translation of which was: "Our dear Imam said that the occupying [Zionist] regime had to be wiped off the face of the earth. This was a very wise statement" 22 . In essence, what the Iranian government was doing was trying to regain ideological supremacy over the Muslim

18 The UN-GA and UNESCO resolutions can be found at: UNESCO. URL: https://wayback.archiveit.org/10611/20160804050411/http://www.unesco.org/dialogue/en/sources.htm/ (accessed 10.07.2015).

19 The list of UNESCO conferences can be found at: UNESCO Conferences. URL: http://www.unesco.org/dialogue/en/conferences.html (accessed 10.07. 2015).

${ }^{20}$ For more information on the Foundation for Dialogue among Civilizations see: URL: http://dialoguefoundation.org/ (accessed 10.07. 2017).

${ }^{21}$ In August 2002 the Iranian dissident journalist Ali Reza Jafarzadeh revealed the existence of Natanz and Arak nuclear facilities, which were unknown by the AIEA and UN, forcing Khatami to declare them to the Atomic Agency, to unilaterally implement the "additional protocols," and to start a serious negotiation with the EU-3 group. For more information on this revelation see URL: http://www.alirezajafarzadeh.org/ (accessed 10.08.2015).

22 The whole speech, translated directly from Persian is available at Voltairenet. Voltairenet. URL: http://www.voltairenet.org/article131510.html (accessed 10.08.2015). 
and Arab people by attracting regional anti-Israeli activism behind a new champion, Ahmadinejad. Same target than the previous president Khatami, but with a very different diplomatic and narrative tools to achieve the regional aspirations and to boost SouthSouth cooperation. While Khatami, as well as Rafsanjani, seemed to be more sympathetic to normalize relations with Europe and even the United States, Ahmadinejad clearly discarded that option, focusing his diplomatic efforts on Africa and mainly Latin America - a region where populist-style governments with a clear anti-American sentiment felt attractive having a Middle East regional power as an ideological ally.

When Ahmadinejad was in his second term in office, the Arab Spring affected the whole Middle East region. It was notable that while the Leader Khamenei clearly stated that the revolts were an "Islamic awakening," Ahmadinejad initially used the words "American awakening" and then "human awakening" to define the events that he considered to be linked to the U.S. agenda of interference in the Middle East. According to him, the United States was aiming to "replace the dictators of the region in order to maintain its own as well as Israel's security" [Haji-Yousefi 2012].

Apart from the nuclear and Syria issues, during Ahmadinejad's term, Iran also gained a major boost among the non-aligned countries at a time of ostracism by the major powers. It was elected chair of the Non-Aligned Movement for the 2012-2015 term, and in that capacity, hosted the $16^{\text {th }}$ NAM Summit in 2012, the most important international conference it had hosted since 1979. Importantly, Iran gained the unanimous support of the non-aligned countries for its right to ownership of a full nuclear cycle (including uranium enrichment). Although the conference did not endorse Iran's position on Syria (all mention of which was omitted in the final declaration), with Egypt's Mohammed Morsi going so far as to publicly repudiate the Assad regime, the conference represented a major diplomatic achievement for $\operatorname{Iran}^{23}$.

A special focus should be done on the close relation that Iran fostered with Latin American states with populistic governments, such as Brazil (da Silva); Cuba (Castro); Ecuador (Correa); Bolivia (Morales) and specially Venezuela (Chavez). Even though the Iranian interest for Latin America was not new - for instance, Khatami visited Venezuela three times during his tenure - the increase in the bilateral trade and political exchanges was exponential during Ahmadinejad tenure. Even the Iran - Venezuela bi-national bank with a $2 \$$ billion fund, was opened during Khatami administration, but started its activities in 2009, receiving a heavy support from both governments in order to tackle the effects of the UN and EU sanctions against Iran on the nuclear dossier. During Ahmadinejad period, Iran obtained the status of the observer in the Bolivarian Alliance (ALBA) formed by Ecuador, Nicaragua, Venezuela, and Bolivia.

Clearly, the re-approach to Latin American countries as well as African ones, and the disaffection with the previous Khatami's détente policy with Europe (and the US), recovering the references of Islamic identity and the discourse of the Islamic revolution, represented the recovery of the most Third-Worldist orientation of the Islamic Republic since 1979 [Arghavani 2013; Haji-Yousefi 2010].

${ }^{23}$ Erdbrink T. Nonaligned Nations Back Iran's Nuclear Bid, but Not Syria. New York Times, August 31, 2012. URL: http://www.nytimes.com/2012/09/01/world/middleeast/iran-criticizes-egyptsmohamed-morsi-over-syria-comments.html?_r=0 (accessed 10.11.2015). 


\section{ROUHANI'S FOCUS ON NUCLEAR DOSSIER}

The current president Hassan Rouhani prioritized the solution of the nuclear controversy with the international community, thus, seriously engaging in nuclear negotiations. As a result, a Joint Comprehensive Plan of Action was signed in April 2015, in which Iran was guaranteed the right to a full cycle of nuclear development and the promise of the lifting of sanctions, in exchange for suspending its uranium enrichment activities and agreeing to complete transparency and supervision of the whole program for a 25-year period. The leader Khamenei tacitly supported the agreement, even though he allowed the critical factions, including the Revolutionary Guard, to express their concerns and opposition to the deal. An important sidelight to the negotiations was the recognition for the first time by the United States of the binding nature of a politicalreligious statement made by Iran's leader. President Obama noted: "Since Iran's Supreme Leader has issued a fatwa against the development of nuclear weapons, this framework gives Iran the opportunity to verify that its program is, in fact, peaceful" 24 .

Despite the worldwide acceptation of the JCPOA, the reception in the Middle East and the Gulf region has not been positive. The U.S. and international recognition of the Iranian rights and the credibility won by the Rouhani administration should have reverberated in the region. Instead, the negative reception by some regional actors, and moreover, the huge pressure exerted on the Obama administration in order to prevent the deal from being signed ${ }^{25}$, showed that the view of a "normalized" Iran with nuclear energy and much more influence, is something that states such as Israel and Saudi Arabia would never accept. This concern was evident at the Gulf Cooperation Council (GCC) summit held in Doha on December 7, 2014, when the six members decided to create a joint naval force to protect the Gulf waters, demonstrating their concern regarding Iran to become a nuclear power and regional hegemon ${ }^{26}$. While Iran may have gained ground (on this issue) with the great powers due to the signature of the JCPOA and its fulfilment of the road map supervised by the International Atomic Energy Agency, it was clearly rejected in its bid for more regional power.

Moreover, since 2017, with the re-election of Hassan Rouhani, the anti-Iranian sentiment in the Persian Gulf and Middle East region seemed to have increased. As a result of the regional confrontation with Saudi Arabia and other regional actors, the regional organizations such as the Gulf Cooperation Council, the Arab States League

${ }^{24}$ White House. Office of the Press Secretary. 2015. Statement by the President on the Framework to Prevent Iran from Obtaining a Nuclear Weapon. April 2. URL: https://www.whitehouse.gov/ the-press-office/2015/04/02/statement-president-framework-prevent-iran-obtaining-nuclear-weapon (accessed 10.11.2015).

${ }^{25}$ The Saudi Prince Turki al Faisal raised an alarm about the beginning of a nuclear race and the increasing Iranian influence in the region (see Iran deal could start nuclear fuel race - Saudi Arabia. URL: http://www.bbc.com/news/world-middle-east-31901961 (accessed 10.11. 2015); the Israeli Prime Minister Benjamin Netanyahu warned the United States against "paving the way to an Iran bomb". URL: http://www.bbc.com/news/world-middle-east-31716684 (accessed 10.11. 2015)).

${ }^{26}$ Dergham R. The Doha GCC Summit: A Turning Point in Gulf Ties. Alarabiya News. 07 December 2014. URL: http://english.alarabiya.net/en/views/news/middle-east/2014/12/07/The-Doha-GCCSummit-A-turning-point-in-Gulf-ties-.html (accessed 9.11.2015). 
and the Organization of Islamic Cooperation, represented a forum in which a strong criticism and condemnation were expressed against Iran. Saudi Arabia which throughout the history of the new Middle East considered itself as one of the main actors for ArabIslamic world forming blocs of power with other monarchies in the Gulf [Diansaei 2018]. In contraposition to what happened during Khatami's era, in which the OIC welcomed and Iranian initiative assuming it as its own, now the same forum became the recipient of the harshest anti-Iranian positions. To some extent, the priority given by Rouhani to the nuclear file, as the main foreign policy tool to reactivate the economy and to normalize Iranian relations with the international community, the US and the EU, backfired in terms of cooperation with the Muslim and Third World states, leaving the ground to a new anti-Iranian narrative and further isolationism within the South context. Moreover, possible failure of the JCPOA after the US withdrawal and the imposition of new sanctions may bring Iran back to square zero in its attempt of becoming a regional power with the recognition of the world powers and regional neighbors.

\section{CONCLUSION}

The article provides an overview of the foreign policy determinants implemented by Iran along its recent history. A special focus is made on the foreign policy tools analysis - mainly since the establishment of the Islamic Revolution - aimed to achieve Iran's long-term objective of becoming a strong regional power. In reaching this goal all the Iranian revolutionary administrations followed a strategy of advancing the SSC that was regarded as the main vehicle for transmiting the anti-imperialistic discourse established by Khomeini in 1979.

The active involvement in regional and international organizations of Global South (NAM, G77 and OIC) in the framework of SSC seemed to have a fundamental function in pushing Iran closer to its strategic goal. The international forums were used by Iran's different administrations, mainly Khatami, Ahmadinejad and Rouhani, as platforms for attracting support for its crucial initiatives (Dialogue among Civilizations, civil nuclear program).

Foreign policy strategy with special focus on SSC as a priority was obviously combined with the Islamic ideology underlying the structure and principles of the Republic, coined by Khomeini and fixed in the constitution. Although South-South cooperation may be viewed as a mere instrumental tool to deliver the message of the Islamic Revolution worldwide, the diverse type of involvement of Iran in different institutions proved that the pragmatism and regionalism are actually the proper tools to foster cooperation in South-South context.

\section{REFERENCES}

Afrasiabi, K. (1994). After Khomeini. New Directions in Iran's Foreign Policy. Boulder, CO: Westview Press.

Acharya, A. (2016). Studying the Bandung conference from a Global IR perspective. Australian Journal of International Affairs, 70 (4), 342-357. DOI: https://doi.org/10.1080/ 10357718.2016.1168359.

Arghavani Pirsalami, F. (2013). Third Wordism and Ahmadinejad's Foreign Policy. Iranian Review of Foreign Affairs, 4 (2), 81-109.

Barzegar, K. (2010). Regionalism in Iran's Foreign Policy. Discourse: An Iranian Quarterly, 9 (3-4), 37-56. 
Dehshiri, M.R. \& Majidi, M.R. (2008). Iran's Foreign Policy in Post-Revolution Era: A Holistic Approach. The Iranian Journal of International Affairs, XXI (1-2), 101-114.

Diansaei, B. (2018). Iran and Saudi Arabia in the Middle East: leadership and sectarianism (20112017). Vestnik RUDN. International Relations, 18 (1), 124 - 134. https://doi.org/10.22363/23130660-2018-18-1-124-134.

Esposito, J.L. \& Piscatori, J. (Eds.). (1990). The Iranian Revolution: Its Global Impact. Miami, FL: Florida International University Press.

Halliday, F. (1979). Iran: Dictatorship and Development. New York: Penguin.

Haji-Yousefi, A.M. (2010). Iran's Foreign Policy during Ahmadinejad: From Confrontation to Accommodation. Paper presented to the Annual Conference of the Canadian Political Science Association June 2-3, 2010, Concordia University, Montreal, Canada.

Haji-Yousefi, A.M. (2012). Iran and the 2011 Arab Revolutions: Perceptions and Actions. Discourse: An Iranian Quarterly, 10 (1-2), 23-60.

Khamenei, the Hassan and Hossein Doctrines, and 'Heroic Flexibility' versus 'Heroic Resistance' in Nuclear Negotiations. (2013). IranPolitik, The Iran Political Analysis Project. URL: http:/www.iranpolitik.com/2013/09/20/analysis/khamenei-hassan-hossein-doctrines-heroicflexibility-heroic-resistance/ (accessed 10.11. 2015).

Ramazani, R.K. (1990). Iran's Export of the Revolution: Politics, Ends and Means. In: The Iranian Revolution: Its Global Impact. Ed. by John Esposito, Miami: Florida International University Press, p. $41-57$.

Ramazani, R.K. (2004). Ideology and Pragmatism in Iran's Foreign Policy. The Middle East Journal, $58(4), 1-11$.

Rodriguez Zahar, L. (1991). La Revolución Islámica-clerical de Irán, 1978-1989. Mexico City: El Colegio de México.

Zaccara, L. (2016a). Iran's permanent quest for regional power status. In: Diplomatic Strategies of Leading Nations in the Global South: Asia, Africa, Latin America, and the Middle East. Ed. by Braveboy-Wagner J. New York: Palgrave Macmillan, p. 181-211.

Zaccara, L. (2016b). From Dialogue of Civilizations to Alliance of Civilizations: Iranian and Spanish initiatives revisited. International Studies Journal, 12 (3), 63-75.

Received: 15.08 .2018

For citations: Zaccara, L. (2018). Iran's Foreign Policy and South-South Cooperation. Vestnik RUDN. International Relations, 18 (3), 550 - 564. DOI: 10.22363/2313-0660-2018-18-3-550-564.

About the Author: Luciano Zaccara - PhD in Arab and Islamic Studies, Assistant Professor, Research Coordinator in Gulf Politics, Qatar University, Qatar (e-mail: luciano.zaccara@qu.edu.qa).

DOI: $10.22363 / 2313-0660-2018-18-3-550-564$

\section{ВНЕШНЯЯ ПОЛИТИКА ИРАНА И ДИНАМИКА СОТРУДНИЧЕСТВА ЮГ-ЮГ}

Л. Заккара

Катарский университет, Доха, Катар

Исламская Республика Иран является одним из наиболее активных участников в формате сотрудничества Юг-Юг. В годы холодной войны сотрудничество Юг-Юг выступало для Ирана способом обеспечения независимой внешней политики и защиты прав «обездоленных» народов от угнетения со стороны колонизаторов и империалистов. В настоящее время это сотрудничество является инструментом борьбы Ирана за региональное превосходство на Ближнем Востоке и в мусульманском мире. 
В статье рассмотрены иранские внешнеполитические стратегии и детерминанты с периода правления шаха Пехлеви вплоть до президентства Хасана Роухани. Цель статьи состоит в том, чтобы оценить, были ли полезны инструменты, используемые для содействия сотрудничеству Юг-Юг в качестве средства достижения международного признания, для реализации долгосрочной цели внешней политики Ирана по превращению в региональную державу, принятую и признанную всем международным сообществом.

Автор использует качественные методы, анализируя литературу по внешней политике Ирана, особенности иранских инициатив в рамках сотрудничества Юг-Юг в постбиполярную эпоху в годы президентства А.А. Хашеми Рафсанджани, М. Хатами, М. Ахмадинежада и Х. Роухани, объясняя суть стратегии «неприсоединения» и тьер-мондизма в иранской внешней политике.

В статье также рассматривается деятельность Ирана в международных организациях «Глобального Юга», таких как Движение неприсоединения (ДН), Организация исламского сотрудничества (ОИС), «Группа 77» и т.д.

Ключевые слова: Иран, сотрудничество Юг-Юг, «исламская революция», стратегия «неприсоединения», «Диалог цивилизаций», тьер-мондизм

Дата поступления статьи: 15.08.2018

Для цитирования: Zaccara L. Iran's Foreign Policy and Evolving Role of South-South Cooperation // Вестник Российского университета дружбы народов. Серия: Международные отношения. 2018. Т. 18. № 3. С. 550-564. DOI: 10.22363/2313-0660-2018-18-3-550-564.

Сведения об авторе: Лучиано Заккара - доктор философии в области арабских исследований и исламоведения, доцент, координатор исследований политики Залива, Катарский университет, Катар (e-mail: luciano.zaccara@qu.edu.qa). 